\title{
Five New Basidioblastomycetous Yeast Species Segregated from Cryptococcus vishniacii emend. auct., an Antarctic Yeast Species Comprising Four New Varieties
}

\author{
HELEN S. VISHNIAC AND SIAVASH BAHARAEEN \\ Department of Microbiology, Oklahoma State University, Stillwater, Oklahoma 74078
}

\begin{abstract}
The Cryptococcus vishniacii complex (H. S. Vishniac and W. P. Hempfling, Int. J. Syst. Bacteriol. 29:153-158, 1979) consists of seven species possessing less than 52\% deoxyribonucleic acid (DNA)-DNA homology: Cryptococcus lupi, $C$. vishniacii, and five new species. Cryptococcus vishniacii Vishniac and Hempfling emend. auct. (additional characters include assimilation of L-aspartate, L-glutamate, 2-ketogluconate, and succinate) includes $C$. vishniacii var. vishniacii var. nov. (MYSW 304Y268 = ATCC 36649) assimilating (besides substrates common to the species) L-arabinose, citrate, L-proline (weakly), sucrose, raffinose, and Lrhamnose (weakly); C. vishniacii var. wolfii var. nov. (MYSW 303Y216 = ATCC 46404), differing from $C$. vishniacii var. vishniacii in assimilating fumarate and Lmalate but not $\mathrm{L}$-arabinose, citrate, sucrose, and raffinose; $C$. vishniacii var. asocialis var. nov. (MYSW 302Y312 = ATCC 46402), differing from C. vishniacii var. vishniacii in assimilating fumarate and $\mathrm{L}$-malate but not $\mathrm{L}$-arabinose or citrate; and C. vishniacii var. vladimiri var. nov. (MYSW 302Y265 = ATCC 46403) differing from $C$. vishniacii var. vishniacii in assimilating cellobiose, methyl- $\alpha$-D-glucoside, and salicin but not L-proline or L-rhamnose. Cryptococcus asgardensis sp. nov. (MYSW 302Y310 = ATCC 46399) differs from $C$. vishniacii in being suppressed by $0.05 \mu \mathrm{g}$ of cycloheximide $\mathrm{ml}^{-1}$ and differs from all other described yeasts in that it produces cream-colored colonies, utilizes $\mathrm{NO}_{3}{ }^{-}-\mathrm{N}$, and assimilates L-arabinose, cellobiose, melezitose, and L-rhamnose but not Dgalactose, myo-inositol, or D-mannitol. Cryptococcus baldrensis sp. nov. (MYSW 302 Y259 = ATCC 46400) differs from all other described yeasts in that it produces cream-colored colonies, utilizes $\mathrm{NO}_{3}{ }^{-}-\mathrm{N}$, and assimilates $\mathrm{L}$-arabinose, cellobiose, 2-ketogluconate, and melezitose but not D-mannitol or succinate. Cryptococcus hempflingii sp. nov. (MYSW 306Y212 = ATCC 46401) differs from all other described yeasts in that it utilizes $\mathrm{NO}_{3}{ }^{-}-\mathrm{N}$ and assimilates melezitose and $\mathrm{D}$ xylose but not D-mannitol, salicin, or succinate. Cryptococcus tyrolensis $\mathbf{s p}$. nov. (MYSW 303Y336 = ATCC 46405) differs from all other described yeasts in that it produces cream-colored colonies, utilizes $\mathrm{NO}_{3}{ }^{-} \mathrm{N}$, and assimilates $\mathrm{L}$-arabinose, melezitose, salicin, and D-xylose but not cellobiose or D-mannitol. Cryptococcus wrightensis sp. nov. (MYSW 303Y206 = ATCC 46406) differs from all other described yeasts (except $C$. vishniacii) in producing cream colonies and in utilizing $\mathrm{NO}_{3}{ }^{-}-\mathrm{N}$ and assimilating cellobiose, citrate, and melezitose but not $\mathrm{L}-$ arabinose, glycerol, or D-mannitol. $C$. wrightensis is phenotypically most similar to $C$. vishniacii var. vladimiri, differing from it by assimilating fumarate (weakly) and L-malate but not L-arabinose. Keys for yeast identification should include varietal listings.
\end{abstract}

Examination of deoxyribonucleic acid (DNA)DNA homologies between the biotypes originally described as Cryptococcus vishniacii (16), an Antarctic basidioblastomycete, has shown that only eight of these biotypes can be considered conspecific with the type isolate and its biotype (3). The description of $C$. vishniacii therefore requires emendation and is herewith emended by the original authors. The remaining biotypes include Cryptococcus lupi (5) and five additional species here proposed: Cryptococcus asgardensis sp. nov., Cryptococcus baldrensis sp. nov., Cryptococcus hempflingii sp. nov., Cryptococcus tyrolensis sp. nov., and Cryptococcus wrightensis sp. nov. Since the identification of C. wrightensis requires keying at subspecific levels, we propose varietal names for those biotypes or biotypical series of $C$. vishniacii 
which are both genetically distinct and readily identifiable.

\section{MATERIALS AND METHODS}

The methods used for electron microscopy are given in reference 4 , for determining the guanine plus cytosine $(G+C)$ content of DNA (buoyant density) in reference 3 , and for ubiquinone identification in reference 5 .

Carbon and nitrogen utilization profiles (and amylose production) were determined by previously reported methods (16) unless described below. Compounds tested as sole sources of carbon and energy were: acetate, L-amino acids (alanine, arginine, aspartate, glutamate, glycine, isoleucine, lysine, methionine, ornithine, phenylalanine, proline, valine), $\gamma$ aminobutyrate, D-arabinose, L-arabinose, D-arabitol, L-arabitol, butyrate, cellobiose, citrate, decane, erythritol, ethanol, fructose, D-fucose, fumarate, galactitol, D-galactose, D-glucitol, $\delta$-gluconolactore, D-glucuronate, glucose, glucosamine, glycerol, myo-inositol, inulin, 2-ketogluconate, 5-ketogluconate, DL-lactate, lactose, L-malate, maltose, mannose, melezitose, melibiose, methanol, methyl- $\alpha-D-$ glucoside, raffinose, $L-$ rhamnose, ribitol, D-ribose, salicin, L-sorbose, starch, succinate, sucrose, trehalose, xylitol, and D-xylose. Compounds tested as sole sources of nitrogen were: $\mathrm{NH}_{4} \mathrm{Cl}, \mathrm{KNO}_{3}$, adenine, D-alanine, L-amino acids (as listed for carbon sources plus L-histidine and L-tyrosine), creatinine, cytosine, ethylamine, guanine, hypoxanthine, nicotinic acid, thiamine, thymine, and uracil. Results are not reported for adenine, guanine, and hypoxanthine- $\mathrm{N}$ since cross-feeding appeared on multiply inoculated plates of all media used. All other substrates should be considered to be nonassimilated in the absence of further mention.

Since yeasts of the $C$. vishniacii complex grow more reliably from small inocula in more highly diluted media, the use of differentiating carbon and nitrogen sources was repeated in medium Y-2 (mineral base of potassium phosphate, $\mathrm{pH} 6.0,1 \mathrm{mM} ; \mathrm{NaCl}, 50 \mathrm{mM}$; $\mathrm{MgSO}_{4} \cdot 7 \mathrm{H}_{2} \mathrm{O}, 0.2 \mathrm{mM}$; chelated trace metals solution [17], $1 \mathrm{ml} \mathrm{liter}^{-1}$; to which was added vitamins as required, $2 \mathrm{mM} \mathrm{NH} \mathrm{NH}_{4} \mathrm{Cl}$ or another nitrogen source, and $0.2 \%$ glucose or another substrate) and medium $Y$ 2S (Y-2 medium supplemented with phosphate buffer to $5 \mathrm{mM}$, N supplied as $0.2 \mathrm{mM} \mathrm{NH} \mathrm{m}_{4} \mathrm{Cl}$, and $0.2 \mathrm{mM}$ sodium hydride glutamate [pH 6.0], with $0.0125 \%$ yeast extract). The supplements in medium Y-2S allow more rapid growth without significantly increasing background growth in the absence of substrates. The results differ from those previously reported with respect to the assimilation of methyl- $\alpha-D$-glucoside: biotype 3 (weak assimilation reported in reference 16) does not assimilate this substrate (we assume some growth-stimulating factor to have been present in trace amounts), and biotype 14 ( $C$. baldrensis) does assimilate it, as does an undescribed biotype which gives equivocal results on other media.

When Y-2 or Y-2S medium is used, the assimilation of sucrose must be determined in individual containers, since cross-feeding may occur on multiply inoculated plates. Amylose is not produced in these media. Amylose formation by these yeasts is not $\mathrm{pH}$ dependent, but it does require higher concentrations of both rapidly available carbon sources and ammonium. The critical condition for this "overflow" phenomenon is ammonium inhibition (unpublished data).

The production of extracellular proteinases which clear skim milk powder $(0.25 \%)$ was examined by using a variant of this medium without inorganic nitrogen (positive controls: Candida aquatica ATCC 18805, Phaffia rhodozyma ATCC 24202). Melanin formation from dihydroxyphenylalanine (DOPA) was examined on solid ( $2.0 \%$ agar) Y-2 medium modified as described by Nurudeen and Ahearn (13) to contain $0.05 \%$ glucose, $0.2 \mathrm{mM} \mathrm{NH}_{4} \mathrm{Cl}, 0.2 \mathrm{mM}$ sodium hydride glutamate $(\mathrm{pH} \mathrm{6.0)}, 5 \mathrm{mM}$ potassium phosphate buffer (pH 6.0), and $0.2 \mathrm{~g}$ of DOPA liter ${ }^{-1}$ (positive control, Filobasidiella neoformans NIH 12).

The lists of minimal presumptive characters were compiled with the aid of R. J. Pankhurst's polyclave (6) and subsequent basidioblastomycete literature.

\section{RESULTS}

Cryptococcus vishniacii Vishniac and Hempfling emend. auct. Int. J. Syst. Bacteriol. 29:153-158 (1979).

Descriptioni primae addenda: Acidum asparticum, acidum glutamicum, acidum 2-ketogluconicum, acidum succinumque assimilant omnes varietates. Methanolum non assimilant. Media tyrosino atrescentes sed non DOPA. Proteinum lactis non hydrolysans. Cum cycloheximide 0.05 $\mu \mathrm{g} / \mathrm{ml}$ haud, $0.5 \mu \mathrm{g} / \mathrm{ml}$ non crescit. Co- $\mathrm{Q}_{9}$ continens; DBB diazonium blue $B$ respondens. $\mathrm{G}+\mathrm{C}$, $54.52( \pm 0.32)$ to $55.48( \pm 0.21) \mathrm{mol} \%$.

The original description should be modified by the following: all varieties assimilate L-aspartate, L-glutamate, 2-ketogluconate, and succinate but not methanol; darken media containing tyrosine but not DOPA; and do not hydrolyze milk protein. All varieties are inhibited by 0.05 $\mu \mathrm{g}$ cycloheximide $\mathrm{ml}^{-1}$ and suppressed by 0.5 $\mu \mathrm{g}$ cycloheximide $\mathrm{ml}^{-1}$, contain coenzyme $\mathrm{Q}_{9}$ (Co- $Q_{9}$ ), and are diazonium blue B (DBB) positive. Nuclear DNA contains $54.52( \pm 0.32)$ to $55.48( \pm 0.21) \mathrm{mol} \% \mathrm{G}+\mathrm{C}$. Figure 1 illustrates the type isolate, MYSW 304 Y268 (= ATCC 36649).

The species comprises the following varieties:

Cryptococcus vishniacii var. vishniacii var. nov. Vishniac and Baharaeen. This variety is considered to include all isolates which resemble the type of the species and variety, MYSW 304Y268, in assimilating L-arabinose, citrate, Lproline (weakly), sucrose, raffinose, and Lrhamnose (weakly), but not cellobiose, fumarate, L-malate, methyl- $\alpha$-D-glucoside, or salicin.

Haec typus speciei et similes quae L-arabinosum, acidum citricum, L-prolinum (lente), sucrosum, raffinosum, L-rhamnosumque (lente) sed non cellobiosum, acidum fumaricum, acidum $\mathrm{L}_{-}$ malicum, methyl- $\alpha$-D-glucosidum, salicinumque assimilant.

Cryptococcus vishniacii var. wolfi var. nov. Vishniac and Baharaeen. (wolf'i.i. M.L. gen. n. 

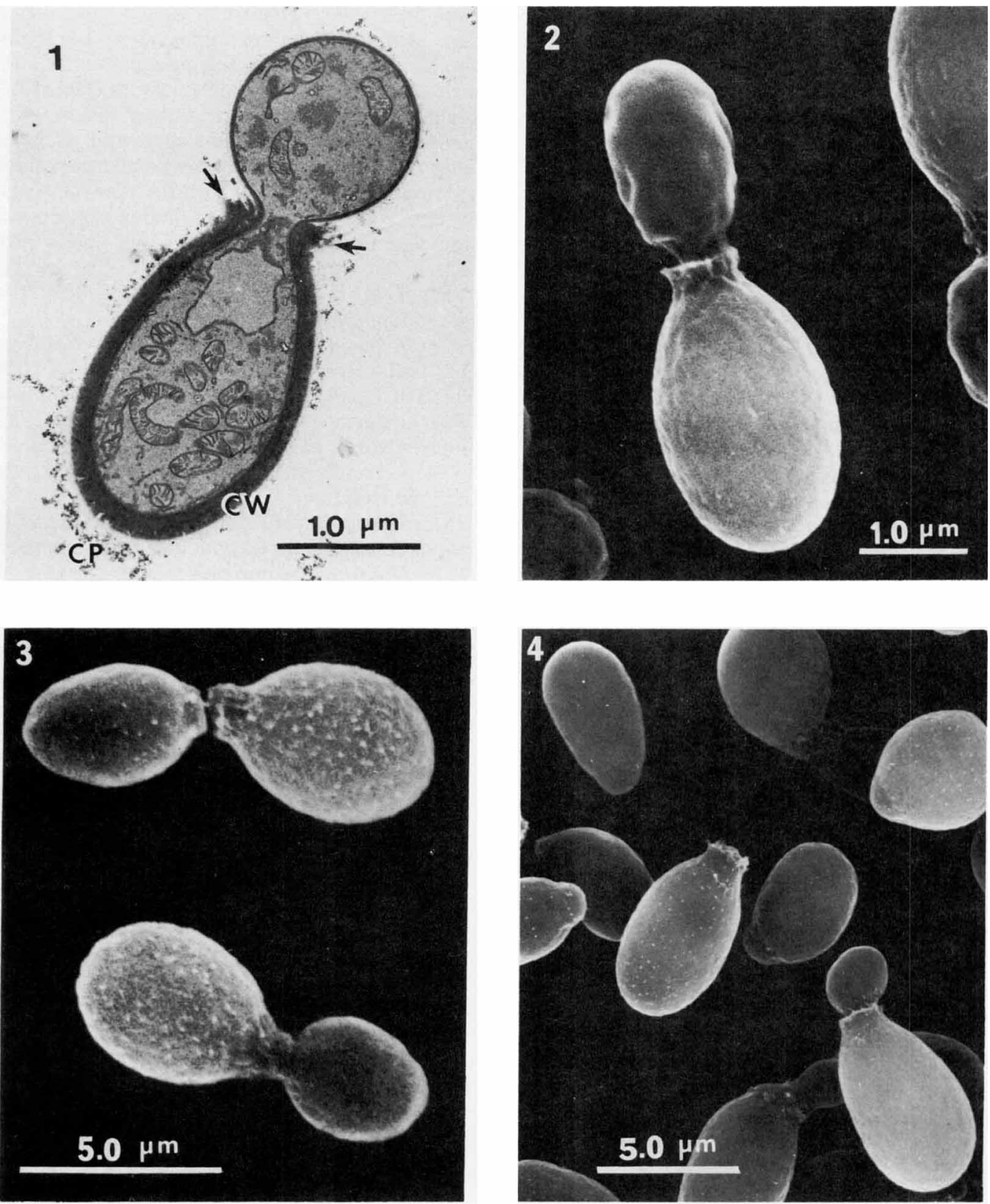

FIG. 1. Transmission electron micrograph of $C$. vishniacii var. vishniacii (MYSW 304Y268, type of species and variety). The bud scar consisting of a ragged collar (characteristic of basidioblastomycetes) is clearly visible (arrows). The cell wall (CW) is not sharp in outline and is surrounded by the fibrillar remains of the capsule (CP).

FIG. 2. Scanning electron micrograph of $C$. asgardensis (MYSW 302Y310, type of species), showing the typical collar and the smoothly granular capsule.

FIG. 3. C. tyrolensis (MYSW 303Y336, type of species). Collar and the nodulated capsule are visible.

FIG. 4. C. wrightensis (MYSW 303Y206, type of species). The curvature observed in some buds is due to the higher growth temperature $\left(15\right.$ rather than $\left.10^{\circ} \mathrm{C}\right)$. The different appearance of the capsular materials in Fig. 2, 3, and 4 may be artifacts caused by critical-point drying. 
wolfii of wolf; named in honor of Wolf Vladimir Vishniac.)

This variety includes those isolates (originally described as biotypes 1 and 2) differing from the type of the species in assimilating fumarate and L-malate but failing to assimilate L-arabinose, citrate, sucrose, and raffinose. It is typified by MYSW 303Y216 (= ATCC 46404) from soil, Tyrol Valley, 4,700 ft (ca. 1,433 m).

Differt a $C$. vishniacii var. vishniacii qua acidum fumaricum $L$-malicumque assimilat sed $L$ arabinosum, acidum citricum, sucrosum, raffinosumque non assimilat. Typus MYSW 303Y216 (= ATCC 46404), e solo, Vallis Tyrol, 4,700 p.

Cryptococcus vishniacii var. asocialis var. nov. Vishniac and Baharaeen. (a.so.ci.al'is. L. adj. asocialis without companionship; referring to its occurrence in barren soil.)

This variety is typified by MYSW 302 Y 312 (= ATCC 46402), from soil, Mt. Baldr, $4,870 \mathrm{ft}$ (ca. 1,485 m), but includes those biotypes which are genetically distinct but not distinguishable by substrate assimilation. This variety differs from the type variety of the species in assimilating fumarate and $\mathrm{L}$-malate but failing to assimilate $\mathbf{L}$-arabinose and citrate.

Differt a $C$. vishniacii var. vishniacii qua acidum fumaricum acidum $L$-malicumque assimilat sed nec L-arabinosum nec acidum citricum assimilat. Typus MYSW 302Y312 (= ATCC 46402), e solo, Mons Baldr, 4,870 p.

Cryptococcus vishniacii var. vladimiri var. nov. Vishniac and Baharaeen. (vlad.i.mir'i. M.L. gen. n. vladimiri of Vladimir; named in honor of Wolf Vladimir Vishniac.)

This variety is typified by MYSW 302Y265 (= ATCC 46403), from soil, Mt. Baldr, $4,870 \mathrm{ft}$ (ca. 1,485 m); it includes those isolates (biotypes 10 and 11) which, although genetically distinct, are not distinguishable by substrate assimilation. The variety differs from the type variety of the species in assimilating cellobiose, methyl- $\alpha-D-$ glucoside, and salicin but not L-proline or Lrhamnose.

Differt a $C$. vishniacii var. vishniacii qua cellobiosum, methyl- $\alpha$-D-glucosidumque assimilat sed acidum L-prolinum, L-rhamnosumque non assimilat. Typus MYSW 302Y265, e solo, Mons Baldr, 4,870 p.

The new species of the $C$. vishniacii complex are:

Cryptococcus asgardensis sp. nov. Vishniac and Baharaeen. (as.gard.en'sis. M.L. adj. asgardensis pertaining to the Asgard Range.)

Forma et augmentatione $C$. vishniacii $C$. lupique similes. Cellulae crescentes ca. $5.8 \times 7.3$ $\mu \mathrm{m}$. Cum cycloheximide $0.05 \mu \mathrm{g} / \mathrm{ml}$ non crescit. Co- $\mathrm{Q}_{9}$ continens; DBB respondens. $\mathrm{G}+\mathrm{C}, 55.07$ $( \pm 0.12) \mathrm{mol} \%$ sed sequentia acidorum deoxyribonucleorum minus quam $38 \%$ altribus similes.
Fermentatio nulla. Assimilat L-arabinosum, acidum $\mathrm{L}$-asparticum, cellobiosum, acidum citricum, fructosum, glucosum, acidum glucuronicum, acidum L-glutamicum, acidum 2-ketogluconicum, acidum 5-ketogluconicum (lentissime), maltosum, mannosum, melezitosum, methyl- $\alpha-$ D-glucosidum, raffinosum, L-rhamnosum, salicinum, acidum succinicum, sucrosum, trehalosum, D-xylosumque. Media tyrosino atrescentes sed non DOPA. Amylosum formatum est. Crescit cum nitrato, acidibus aminibusque. Crescit sine vitaminis. Nec gelatinum nec lactis proteinum nec urea finduntur.

Typus MYSW $302 Y 310$ (= ATCC 46399), e solo, Mons Baldr, 4,870 p.

Cryptococcus asgardensis sp. nov. Vishniac and Baharaeen is typified by isolate MYSW 302 Y310 (= ATCC 46399), isolated from soil (dolerite terrace) near the middle of the east slope $(4,870 \mathrm{ft}$; ca. $1,485 \mathrm{~m})$ of Mt. Baldr, South Victoria Land, Antarctica. Figure 2 illustrates the type isolate.

Morphology and development are similar to that of $C$. vishniacii, C. lupi, and other members of the $C$. vishniacii complex, in which the type was originally described as biotype 16 . Exponentially growing cells average approximately 5.8 by $7.3 \mu \mathrm{m}$. Growth is suppressed by $0.05 \mu \mathrm{g}$ of cycloheximide $\mathrm{ml}^{-1}$. The species contains Co- $\mathrm{Q}_{9}$ and responds positively to DBB. Nuclear DNA contains $55.07( \pm 0.12) \mathrm{mol} \% \mathrm{G}+\mathrm{C}$ but exhibits less then $38 \%$ homology with other members of the complex.

Fermentation does not occur. L-Arabinose, Laspartate, cellobiose, citrate, fructose, glucose, glucuronate, L-glutamate, 2-ketogluconate, 5ketogluconate (very slowly), maltose, mannose, melezitose, methyl- $\alpha$-D-glucoside, raffinose, $L$ rhamnose, salicin, succinate, sucrose, trehalose, and D-xylose are assimilated. Amylose may be produced during growth on L-arabinose, glucose, sucrose, or D-xylose. Media ( $\mathrm{Y}-1$ base) containing tyrosine are darkened, but melanin is not produced from L-DOPA. Nitrate and Lamino acids are utilized as $\mathrm{N}$ sources. Vitamins are not required. Gelatin, skim milk proteins, and urea are not hydrolyzed.

Observation of colony color (cream), determination of nitrate utilization (positive), and assimilation of L-arabinose (positive), cellobiose (positive), D-galactose (negative), myo-inositol (negative), D-mannitol (negative), melezitose (positive), and L-rhamnose (positive) will allow presumptive identification of isolates with this species rather than with any other yeast species heretofore described except $C$. vishniacii, from which this species differs only in greater sensitivity to cycloheximide.

C. asgardensis is phenotypically most similar to $C$. vishniacii var. vladimiri, from which it 
differs in L-rhamnose (positive) assimilation and a greater sensitivity to cycloheximide. C. asgardensis shows the greatest DNA-DNA homology to $C$. baldrensis sp. nov. ( 37.7 to $31.6 \%$ in reciprocal hybridizations), from which it differs in L-rhamnose (positive) and succinate (positive) assimilation as well as in cycloheximide sensitivity.

Cryptococcus baldrensis sp. nov. Vishniac and Baharaeen. (baldr.en'sis. M.L. adj. baldrensis pertaining to Mt. Baldr.)

Forma et augmentatione $C$. vishniacii $C$. lupique similes. Cellulae crescentes ca. $5.0 \times 6.5$ $\mu \mathrm{m}$. Cum cycloheximide $0.05 \mu \mathrm{g} / \mathrm{ml}$ haud, 0.5 $\mu \mathrm{g} / \mathrm{ml}$ non crescit. Co-Q 9 continens; DBB respondens. $\mathrm{G}+\mathrm{C}, 54.76( \pm 0.21) \mathrm{mol} \%$ sed sequentia acidorum deoxyribonucleorum minus quam $52 \%$ altribus similes.

Fermentatio nulla. Assimilat acidüm $\gamma$-aminobutyricum, L-arabinosum, acidum $\mathrm{L}$-asparticum, cellobiosum, acidum citricum (lente), fructosum, glucosum, acidum glucuronicum, acidum L-glutamicum, acidum 2-ketogluconicum, maltosum, mannosum, melezitosum, raffinosum, salicinum, sucrosum, trehalosum, D-xylosumque. Media tyrosino atrescentes sed non DOPA. Amylosum formatum est. Crescit cum nitrato, acidibus aminibusque. Crescit sine vitaminis. $\mathrm{Nec}$ gelatinum nec lactis proteinum nec urea finduntur.

Typus MYSW 302Y259 (= ATCC 46400), e solo, Mons Baldr, 4,870 p.

Cryptococcus baldrensis sp. nov. Vishniac and Baharaeen is typified by isolate MYSW 302 Y259 (= ATCC 46400), isolated from soil (dolerite terrace) near the middle of the east slope $(4,870 \mathrm{ft}$; ca. $1,485 \mathrm{~m})$ of Mt. Baldr, South Victoria Land, Antarctica. Illustrations (as biotype 14 of $C$. vishniacii) may be found in reference 4.

Morphology and development are similar to those of $C$. vishniacii, $C$. lupi, and other members of this complex. Exponentially growing cells average about 5.0 by $6.5 \mu \mathrm{m}$. Growth is inhibited by $0.05 \mu \mathrm{g}$ of cycloheximide $\mathrm{ml}^{-1}$ and suppressed by $0.5 \mu \mathrm{g}$ of cycloheximide $\mathrm{ml}^{-1}$. The species contains $\mathrm{Co}_{-} \mathrm{Q}_{9}$ and responds positively to DBB. Nuclear DNA contains 54.76 $( \pm 0.21) \mathrm{mol} \% \mathrm{G}+\mathrm{C}$; the DNA-DNA homology with other biotypes of the $C$. vishniacii complex is less than $52 \%$.

Fermentation does not occur. $\gamma$-Aminobutyrate, L-arabinose, L-aspartate, cellobiose, citrate (weakly), fructose, glucose, glucuronate, L-glutamate, 2-ketogluconate, maltose, mannose, melezitose, raffinose, salicin, sucrose, trehalose, and D-xylose are assimilated. Media (Y-1 base) containing tyrosine are darkened, but melanin is not produced from L-DOPA. Nitrate and Lamino acids are utilized as $\mathrm{N}$ sources. Vitamins are not required. Gelatin, skim milk proteins, and urea are not hydrolyzed.

Observation of colony color, determination of nitrate utilization (positive), and assimilation of L-arabinose (positive), cellobiose (positive), 2ketogluconate (positive), D-mannitol (negative), melezitose (positive), and succinate (negative) will allow presumptive identification of isolates with this species rather than with any other yeast species heretofore described.

$C$. baldrensis shows the closest DNA-DNA homologies to $C$. tyrolensis sp. nov. (51.5\%), from which it differs phenotypically in assimilating cellobiose and citrate (weakly) and to $C$. vishniacii var. vladimiri (50.9 to $48.9 \%)$, from which it differs in its failure to assimilate succinate. This species is also phenotypically similar to $C$. lupi, from which it differs in assimilating 2ketogluconate.

Cryptococcus hempflingii sp. nov. Vishniac and Baharaeen. (hemp.fling'i.i. M.L. gen. n. hempflingii of Hempfling; named in honor of W. P. Hempfling, who first isolated members of the $C$. vishniacii complex.)

Forma et augmentatione $C$. vishniacii $C$. lupique similes. Cellulae crescentes ca. $6.5 \times 8.0$ $\mu \mathrm{m}$. Cum cycloheximide $0.05 \mu \mathrm{g} / \mathrm{ml}$ haud, 0.5 $\mu \mathrm{g} / \mathrm{ml}$ non crescit. Co- $\mathrm{Q}_{9}$ continens; DBB respondens. $\mathrm{G}+\mathrm{C}, 55.34( \pm 0.06) \mathrm{mol} \%$ sed sequentia acidorum deoxyribonucleorum minus quam $46 \%$ altribus similes.

Fermentatio nulla. Assimilat fructosum, acidum fumaricum (lente), glucosum, acidum gluconicum (lentissime, variable), acidum glucuronicum, acidum L-glutamicum (lente), acidum 2ketogluconicum, acidum L-malicum (lente), maltosum, mannosum, melezitosum, raffinosum, L-rhamnosum (lente), sucrosum, trehalosum, D-xylosumque. Media tyrosino atrescentes sed non DOPA. Amylosum formatum est. Crescit cum nitrato, acidibus aminobusque. Crescit sine vitaminis. Nec gelatinum nec lactis proteinum nec urea finduntur.

Typus MYSW 306Y212 (= ATCC 46401), e solo, Vallis Tyrol, 4,750 p.

Cryptococcus hempflingii sp. nov. Vishniac and Baharaeen is typified by isolate MYSW 306Y212 (= ATCC 46401) from soil (sand, sandstone) from the northwest part of Tyrol Valley, 4,750 ft (ca. 1,448 m), South Victoria Land, Antarctica. Illustrations (as biotype 6 of $C$. vishniacii) may be found in reference 4 .

Morphology and development are similar to that of $C$. vishniacii, $C$. lupi, and other members of this complex, in which the species was originally described as biotype 6 . Exponentially growing cells average about 6.5 by $8.0 \mu \mathrm{m}$. Cycloheximide inhibits growth at $0.05 \mu \mathrm{g} \mathrm{ml}^{-1}$ and suppresses growth at $0.5 \mu \mathrm{g} \mathrm{ml} \mathrm{m}^{-1}$. The species contains $\mathrm{Co}-\mathrm{Q}_{9}$ and responds positively 
to DBB. Nuclear DNA contains $55.34( \pm 0.06)$ mol\% G+C; the DNA-DNA homology with other biotypes of the $C$. vishniacii complex is less than $46 \%$.

Fermentation does not occur. Fructose, fumarate (weakly), glucose, gluconate (very slowly, variably), glucuronate, L-glutamate (weakly), 2ketogluconate, L-malate (weakly), maltose, mannose, melezitose, raffinose, L-rhamnose (weakly), sucrose, trehalose, and D-xylose are assimilated. Amylose may be produced during growth on glucose, sucrose, or D-xylose. Media (Y-1 base) containing tyrosine are darkened, but melanin is not produced from L-DOPA. Nitrate and L-amino acids are utilized as $\mathrm{N}$ sources. Vitamins are not required. Gelatin, skim milk proteins, and urea are not hydrolyzed.

Determination of nitrate utilizatioti (positive) and assimilation of D-mannitol (neg....ve), melezitose (positive), salicin (negative), succinate (negative), and D-xylose (positive) will allow presumptive identification of isolates with this species rather than with any other yeast species heretofore described.

Cryptococcus hempflingii is phenotypically most similar to $C$. vishniacii var. asocialis, from which it differs in failure to assimilate L-aspartate, L-proline (C. vishniacii var. asocialis, weak), and succinate. The species shows the most DNA-DNA homology, however, to $C$. vishniacii var. vladimiri (45.9 to $42.2 \%$ in reciprocal hybridizations with MYSW 302Y265), from which it differs phenotypically by failure to assimilate $\mathrm{L}$-arabinose, $\mathrm{L}$-aspartate, cellobiose, citrate, L-glutamate, methyl- $\alpha$-D-glucoside, salicin, and succinate and by weakly assimilating fumarate, L-malate, and L-rhamnose. C. hempflingii and $C$. vishniacii differ in succinate assimilation.

Cryptococcus tyrolensis sp. nov. Vishniac and Baharaeen. (tyrol.en'sis. M.L. adj. tyrolensis pertaining to the Tyrol Valley.)

Forma et augmentatione $C$. vishniacii $C$. lupique similes. Cellulae crescentes ca. $4.6 \times 5.8$ $\mu \mathrm{m}$. Cum cycloheximide $0.05 \mu \mathrm{g} / \mathrm{ml}$ haud, 0.5 $\mu \mathrm{g} / \mathrm{ml}$ non crescit. Co- $\mathrm{Q}_{9}$ continens; DBB respondens. G+C, $55.82( \pm 0.27) \mathrm{mol} \%$ sed sequentia acidorum deoxyribonucleorum minus quam $52 \%$ altribus similes.

Fermentatio nulla. Assimilat L-arabinosum, acidum L-asparticum, fructosum, glucosum, acidum glucuronicum, acidum L-glutamicum, acidum 2-ketogluconicum, acidum 5-ketogluconicum (lentissime), maltosum, mannosum, melezitosum, methyl- $\alpha$-D-glucosidum, raffinosum, salicinum, sucrosum, trehalosum, D-xylosumque. Amylosum formatum est. Crescit cum nitrato, acidibus aminibusque. Media tyrosino atrescentes sed non DOPA. Crescit sine vitaminis. Nec gelatinum nec lactis proteinum nec urea finduntur.
Typus MYSW 303 Y336 (= ATCC 46405), e solo, Vallis Tyrol, 4,700 p.

Cryptococcus tyrolensis sp. nov. Vishniac and Baharaeen is typified by isolate MYSW 303 Y 336 (= ATCC 46405) from soil (dolerite moraine) in the Tyrol Valley, South Victoria Land, Antarctica. Figure 3 illustrates the type isolate.

Morphology and development are similar to those of $C$. vishniacii, C. lupi, and other members of the $C$. vishniacii complex in which this species was originally described as biotype 15 . Exponentially growing cells average about 4.6 by $5.8 \mu \mathrm{m}$. Growth is inhibited by $0.05 \mu \mathrm{g}$ of cycloheximide $\mathrm{ml}^{-1}$ and suppressed by $0.5 \mu \mathrm{g}$ $\mathrm{ml}^{-1}$. The species contains $\mathrm{Co}-\mathrm{Q}_{9}$ and responds positively to DBB. Nuclear DNA contains $\mathbf{5 5 . 8 2}$ ( \pm 0.27$) \mathrm{mol} \% \mathrm{G}+\mathrm{C}$; DNA-DNA homology with other biotypes of the $C$. vishniacii complex is less than $52 \%$.

Fermentation does not occur. L-Arabinose, Laspartate, fructose, glucose, glucuronate, L-glutamate, 2-ketogluconate, 5-ketogluconate (very slowly), maltose, mannose, melezitose, methyl$\alpha$-D-glucoside, raffinose, salicin, sucrose, trehalose, and D-xylose are assimilated. Amylose may be produced during growth on L-arabinose, glucose, sucrose, or D-xylose. Media (Y-1 base) containing tyrosine are darkened, but melanin is not produced from L-DOPA. Nitrate and Lamino acids are utilized as $\mathrm{N}$ sources. Vitamins are not required. Gelatin, skim milk proteins, and urea are not hydrolyzed.

Observation of colony color (cream), determination of nitrate utilization (positive), and assimilation of L-arabinose (positive), cellobiose (negative), D-mannitol (negative), melezitose (positive), salicin (positive), and D-xylose (positive) will allow presumptive identification of isolates with this species rather than with any other yeast species heretofore described.

Cryptococcus tyrolensis is phenotypically most similar to $C$. baldrensis, differing in assimilation of $\gamma$-aminobutyrate (negative), cellobiose (negative), and citrate (negative) and to $C$. wrightensis sp. nov., differing in assimilation of $\gamma$-aminobutyrate (negative), L-arabinose (positive), citrate (negative), and succinate (negative). $C$. tyrolensis showed $51.55 \%$ DNA-DNA homology with $C$. baldrensis; homology with $C$. wrightensis was not measured directly, but it is unlikely to be over $50 \%$. Genetic differences (100 minus percent relative binding of heterologous probe DNA) are not accurate at homologies below roughly $50 \%$, but topological constraints are imposed upon the probable position of loci fixed vectorially in a three-dimensional evolutionary map by the use of a series of probes. The probable position of $C$. tyrolensis is constrained to a genetic difference of not less than $50 \%$ with respect to $C$. wrightensis.

Cryptococcus wrightensis sp. nov. Vishniac 
TABLE 1. Differential characteristics of the C. vishniacii complex ${ }^{a}$

\begin{tabular}{|c|c|c|c|c|c|c|c|c|}
\hline \multirow[b]{2}{*}{ Cryptococcus sp. } & \multicolumn{8}{|c|}{ Growth (assimilation of substrate) } \\
\hline & $\begin{array}{l}\text { Cycloheximide } \\
\left(0.05 \mu \mathrm{g} \mathrm{ml}^{-1}\right)\end{array}$ & L-Arabinose & Cellobiose & Citrate & $\begin{array}{l}\alpha \text {-Methyl-D- } \\
\text { glucoside }\end{array}$ & L-Rhamnose & Succinate & Sucrose \\
\hline $\begin{array}{l}\text { C. vishniacii } \\
\text { var. vishniacii }\end{array}$ & $\mathrm{D}$ & + & 0 & + & 0 & W & + & + \\
\hline $\begin{array}{l}\text { C. vishniacii } \\
\text { var. wolfii }\end{array}$ & D & 0 & 0 & 0 & 0 & W & + & 0 \\
\hline $\begin{array}{l}\text { C. vishniacii } \\
\quad \text { var. asocialis }\end{array}$ & D & 0 & $\mathbf{0}$ & 0 & 0 & W & + & + \\
\hline $\begin{array}{l}\text { C. vishniacii } \\
\text { var. vladimiri }\end{array}$ & D & + & + & + & + & 0 & + & + \\
\hline C. asgardensis & 0 & + & + & + & + & + & + & + \\
\hline C. baldrensis & D & + & + & W & + & 0 & 0 & + \\
\hline C. hempflingii & D & 0 & 0 & 0 & 0 & W & 0 & + \\
\hline C. tyrolensis & D & + & 0 & 0 & + & 0 & 0 & + \\
\hline C. wrightensis & D & 0 & + & + & + & 0 & + & + \\
\hline
\end{tabular}

${ }^{a}$ All species are anamorphic (basidiomycetous), nonfermenting, encapsulated, cream-colored yeasts, monopolar budding, lacking mycelium and psoudomycelium, urease and mannitol negative, and nitrate positive.

${ }^{b} \mathbf{0}$, No growth; +, growth (assimilation of substrates); W, weak growth; D, delayed growth.

and Baharaeen. (wright.en'sis. M.L. adj. wrightensis pertaining to the Wright Valley.)

Forma et augmentatione $C$. vishniacii $C$. lupique similes. Cellulae crescentes ca. $4.8 \times 6.7$ $\mu \mathrm{m}$. Cum cycloheximide $0.05 \mu \mathrm{g} / \mathrm{ml}$ haud, 0.5 $\mu \mathrm{g} / \mathrm{ml}$ non crescit. Co- $Q_{9}$ continens; DBB respondens. $\mathrm{G}+\mathrm{C}, 54.63( \pm 0.06) \mathrm{mol} \%$ sed sequentia acidorum deoxyribonucleorum minus quam $35 \%$ altribus similes.

Fermentatio nulla. Assimilat acidum $\gamma$-aminobutyricum, acidum L-asparticum, cellobiosum, acidum citricum, fructosum, acidum fumaricum (lente), glucosum, acidum glucuronicum, acidum L-glutamicum, acidum 2-ketogluconicum, acidum 5-ketogluconicum (lentissime), acidum L-malicum, maltosum, mannosum, melezitosum, methyl- $\alpha$-D-glucosidum, raffinosum, salicinum, acidum succinicum, sucrosum, trehalosum, D-xylosumque. Amylosum formatum est. Crescit cum nitrato, acidibus aminibusque. Media tyrosino atrescentes sed non DOPA. Crescit sine vitaminis. Nec gelatinum nec lactis proteinum nec urea finduntur.

Typus 303Y206 (= ATCC 46406), e solo, Vallis Tyrol, 4,700 p.

Cryptococcus wrightensis sp. nov. Vishniac and Baharaeen is typified by isolate MYSW 303 Y206 (= ATCC 46406), isolated from soil (dolerite moraine) in the Tyrol Valley (a subsidiary of the Wright Valley), South Victoria Land, Antarctica. Figure 4 illustrates the type isolate.

Morphology and development are similar to those of $C$. vishniacii, C. lupi, and other members of the $C$. vishniacii complex, in which this species was originally described as biotype 9 . Exponentially growing cells average about 4.8 by $6.7 \mu \mathrm{m}$. Growth is inhibited by $0.05 \mu \mathrm{g}$ of cycloheximide $\mathrm{ml}^{-1}$ and is suppressed by $0.5 \mu \mathrm{g}$ of cycloheximide $\mathrm{ml}^{-1}$. The species contains
Co- $\mathrm{Q}_{9}$ and responds positively to $\mathrm{DBB}$. Nuclear DNA contains $54.63( \pm 0.06) \mathrm{mol} \% \mathrm{G}+\mathrm{C}$; DNADNA homology with other biotypes measured less than $35 \%$ and is topologically constrained to less than $50 \%$ with respect to those biotypes not used as probes.

Fermentation does not occur. $\gamma$-Aminobutyrate, L-aspartate, cellobiose, citrate, fructose, fumarate (weakly), glucose, glucuronate, L-glutamate, 2-ketogluconate, 5-ketogluconate (very weakly and slowly), L-malate, maltose, mannose, melezitose, methyl- $\alpha$-D-glucoside, raffinose, salicin, succinate, sucrose, trehalose, and D-xylose are assimilated. Amylose may be produced during growth on glucose or D-xylose. Media (Y-1 base) containing tyrosine are darkened, but melanin is not produced from $\mathbf{L}$ DOPA. Nitrate and L-amino acids are utilized as N sources. Vitamins are not required. Gelatin, skim milk proteins, and urea are not hydrolyzed.

Observation of colony color (cream), determination of nitrate utilization (positive) and assimilation of L-arabinose (negative), cellobiose (positive), citrate (positive), glycerol (negative), Dmannitol (negative), and melezitose (positive) will allow presumptive identification of isolates with this species rather than with any other yeast species heretofore described except $C$. vishniacii.

Cryptococcus wrightensis is almost equally related by DNA-DNA homology (less than 35\%) to the three most homologous probes used $(C$. vishniacii var. vladimiri, C. baldrensis, and $C$. hempflingii) and may be more homologous (less than $50 \%$ ) with $C$. tyrolensis, from which it differs phenotypically in assimilating $\gamma$-aminobutyrate, cellobiose, citrate, and succinate and failing to assimilate L-arabinose. Phenotypically, this species most closely resembles $C$. vishniacii 
var. vladimiri, differing by its failure to assimilate $\mathrm{L}$-arabinose and by assimilating fumarate (weakly) and L-malate. Since these characters vary in the species $C$. vishniacii, $C$. wrightensis and $C$. vishniacii can only be distinguished at the varietal level.

Yeasts of the $C$. vishniacii complex described above can be identified by the characteristics listed in Table 1.

\section{DISCUSSION}

The erection of anamorphic species on the grounds of DNA-DNA homology is debatable; the nature of speciation is such that there can be no absolute homology value which defines conspecificity. We have chosen to regard genetic differences greater than $48 \%$ ( $52 \%$ homology) as excluding conspecificity, because the depleted information content of lower homology values (determined by hybridization techniques) vitiates the construction of three-dimensional evolutionary maps (3).

The only model available among basidiomycetous yeasts is Filobasidiella, the two species of which are sufficiently closely related to show DNA-DNA homology (37 to 45 units of genetic difference, including, however, 9\% homology due to base mismatch). Several $(1,8,14)$ reports of interspecific mating by some isolates do not invalidate Kwon-Chung's $(11,12)$ species; the fertility of the hybrid basidiospores was not determined. A more complete examination of the interaction of the geography, ecology, and genetics of this human pathogen should throw considerable light on the process of speciation in yeasts. A study in which not only the fertility of hybrid ascospores but also the absence of amphidiploidy were determined has shown that ascomycetous yeasts may mate (with markedly diminished fertility) over genetic difference as large as 76 units (10). It is unlikely that such yeasts constitute a continuous genetic pool in their natural habitats, a factor in our choice of species-defining homology level. In C. vishniacii, no variety or biotype is more than 26 units different from another. The unmapped (3) species of the complex may be, at this time, farther apart but not closer than 48 units to other species of the complex. Presumably they were closer at some time in the phylogenetic past, but their present distances could only be bridged by the discovery of several additional biotypes, a possibility limited by available niches and the persistence of isolated populations. Microbes are so diverse that for none of them can either the definition of multidimensional niches or the life history of populations be said to have been adequately explored.

The species which we propose are identifiable by appropriate modifications of standard techniques (15), provided that varietal listings are included in keys. The absence of assimilation profiles at the level of variety or biotype in such widely used compendia as Barnett et al. (7) poses problems for users who are not primarily yeast taxonomists not only in separating $C$. vishniacii from $C$. wrightensis but also in discovering the existence of orphaned varieties whose unknown teleomorph is not that of the type variety of their species. The inclusion of varietal assimilation profiles might greatly simplify ecological studies of such species as Candida humicola, Cryptococcus albidus, Cryptococcus laurentii, Rhodotorula glutinis, Rhodotorula rubra, and Saccharomyces cerevisiae, species whose assimilation profiles (7) contain roughly as many strain-variable as strain-invariable characters.

It is possible that no nonsexual characters will be found to distinguish $C$. vishniacii and $C$. wrightensis or to separate the teleomorphs of $R$. glutinis (Rhodosporidium diobovatum, Rhodosporidium sphaerocarpum, and Rhodosporidium toruloides [9]). Assimilation profiles can be useful in distinguishing taxa only to the extent to which environmental pressures involving differential resource utilization have been important in their evolution. The success of such techniques at the level of species in the characterization and identification of many relatively featureless microbes appears to confirm the intuitively obvious-for man or microbe, sources of support play a major role in survival and reproduction-but they are not the only factors in speciation. Phenotypic similarity indices do not necessarily reffect genetic relationships in yeasts or in other microbes.

\section{ACKNOWLEDGMENTS}

This study was supported by research grant NAGW-26 from the National Aeronautics and Space Administration.

We thank K. J. Kwon-Chung for cultures and Mary Gray and Teresa McElroy for technical assistance.

\section{REPRINT REQUESTS}

Address reprint requests to: Dr. H. S. Vishniac, Department of Microbiology, Oklahoma State University, Stillwater, OK 74078 .

\section{LITERATURE CITED}

1. Ahearn, D. G., and R. L. Schlitzer. 1981. A pyrimidine sporulation medium for Filobasidiella. Mycologia 73:343345 .

2. Aulakh, H. S., S. E. Straus, and K. J. Kwon-Chung. 1981 Genetic relatedness of Filobasidiella neoformans (Cryptococcus neoformans) and Filobasidiella bacillispora (Cryptococcus bacillisporus) as determined by deoxyribonucleic acid base composition and sequence homology studies. Int. J. Syst. Bacteriol. 31:97-103.

3. Baharaeen, S., J. A. Bantle, and H. S. Vishniac. 1982. The evolution of Antarctic yeasts: DNA base composition and DNA-DNA homology. Can. J. Microbiol. 28:406-413.

4. Baharaeen, S., and H. S. Vishniac. 1981. Budding morphology of a psychrophilic Cryptococcus and related 
species compared with Leucosporidium scottii. Mycologia 73:618-633.

5. Baharaeen, S., and H. S. Vishniac. 1982. Cryptococcus lupi sp. nov., an Antarctic basidioblastomycete. Int. J. Syst. Bacteriol. 32:229-232.

6. Barnett, J. A., and R. J. Pankhurst. 1974. A new key to the yeasts. American Elsevier Publishing Co., Inc., New York.

7. Barnett, J. A., R. W. Payne, and D. Yarrow. 1979. A guide to identifying and classifying yeasts. Cambridge University Press, Cambridge.

8. Bowman, P. I., and D. G. Ahearn. 1977. Ecology of Cryptococcus neoformans in Georgia, p. 258-268. Proceedings of the Fourth International Conference on the Mycoses, scientific publication no. 356. Pan American Health Organization, Washington, D.C.

9. Fell, J. W., I. L. Hunter, and A. S. Tallman. 1973. Marine basidiomycetous yeasts (Rhodosporidium spp. n.) with tetrapolar and multiple allelic bipolar mating systems. Can. J. Microbiol. 19:643-657.

10. Kurtzman, C. P., M. J. Smiley, and C. J. UuShnson. 1980. Emendation of the genus Issatchenkia $\mathbf{F}$ driavzev and comparison of species by deoxyribonucleic acid reassociation, mating reaction, and ascospore ultrastructure.
Int. J. Syst. Bacteriol. 30:503-513.

11. Kwon-Chung, K. J. 1975. A new genus, Filobasidiella, the perfect state of Cryptococcus neoformans. Mycologia 67:1197-1200.

12. Kwon-Chung, K. J. 1976. A new species of Filobasidiella, the sexual state of Cryptococcus neoformans B and C serotypes. Mycologia 68:942-946.

13. Nurudeen, T. A., and D. G. Ahearn. 1979. Regulation of melanin production by Cryptococcus neoformans. J. Clin. Microbiol. 10:724-729.

14. Schmeding, K. A., S. C. Jong, and R. Hugh. 1981. Sexual compatibility between serotypes of Filobasidiella neoformans (Cryptococcus neoformans). Curr. Microbiol. 5:133-138.

15. van der Walt, J. P. 1970. Criteria and methods used in classification, p. 34-113. In J. Lodder (ed.), The yeasts-a taxonomic study. North-Holland Publishing Co., Amsterdam.

16. Vishniac, H. S., and W. P. Hempfling. 1979. Cryptococcus vishniacii sp. nov., an Antarctic yeast. Int. J. Syst. Bacteriol. 29:153-158.

17. Vishniac, W., and M. Santer. 1957. The thiobacilli. Bacteriol. Rev. 21:195-213. 